\title{
Impact of Brand Label on Purchase Intention of a Customer
}

\author{
Ahsan Ul Haq1, Irfan Ahmad Kahloon², Aamir Saleem ${ }^{3}$ \\ ${ }^{1}$ Riphah International University Faisalabad, Pakistan \\ ${ }^{2}$ National University of Modern Languages, Pakistan \\ ${ }^{3}$ Government College University Faisalabad, Pakistan \\ ahsanahmad857@gmail.com, ifrfanahmadkahloon@gmail.com, mian.aamersaleem@gmail.com
}

\begin{abstract}
Main target of this research is examining the relationship between the purchase intention of cosmetics and brand label. The image of the store mediates the relationship between purchase intention and brand label in the cosmetics sector of Pakistan. To check the direct or indirect effect of brand label on purchase intention, data was collected from 200 customers of different stores. Snow ball sampling technique is used for the collection of data from respondents, and PLS-SEM 3 was used to test the hypothesis. The findings indicate that brand label positively and significantly impact customer purchase intention of cosmetics and store image is also positively linked with brand label and mediating the relationship between purchase intention and brand label. Findings will help the retail service sector to understand the importance of store image and how to enhance the consumers purchase intentions. Over long term, customer retention is better and business profitability is greater.
\end{abstract}

Key words: Brand Label, Store Image, Purchase Intention

\section{Introduction}

The cosmetics industry has been the bulwark of Pakistan's economy. The garments and cosmetics are the two largest industries and play important role in foreign exchange of the country. The share of the cosmetics industry in the national economy and its contribution to exports, in terms of GDP, foreign exchange earnings, investment, employment and value added, and income generation, altogether the cosmetics industry is seen as a lucrative manufacturing industry in economic growth of the country. Pakistan is rapidly becoming a cosmetics trading centre in Asia. This industry is also among the major employment sector of Pakistan it serve the huge population of Pakistan. The employment rate in this sector in 2017 is $23 \%$ which is highest employment rate as compare to other industry. If we compare the retail industry with cosmetics industry the retail industry is also give the huge employment rate to the Pakistan population. The employment rate in retail industry in 2016 is $21 \%$.

The Pakistan cosmetics industry is among the major industry of Pakistan. In GDP $4.5 \%$ contribute by this sector of Pakistan. This region provides 23\% employment to the total population of Pakistan. In list of cotton producers Pakistan is at no 11 and Pakistan is the 12 largest yarn manufacturers in Asia. Cosmetics industry is the back bone industry of Pakistan. The export of Pakistan cosmetics is decreasing day by day. Due to decrease in cosmetics export we want to promote our retail industry because lack of intension in retail industry. Current era development of Pakistan basically depends on service sector. At this time the service sector contributing 53.30\% to real GDP. Due to continuous growth of service sector in 2004-05 there is positive changes appears in the economy of Pakistan it is very help full in total economic growth. Due to positive changes in economy of Pakistan the purchasing power of the consumer increases, customer need and wants are also changes and the customer focus on more service quality. The term "Retail" is derived from the French word "retailer" which means "cut a piece" or "break volume". Retail includes direct interaction with customers and coordination of end-to-end business activities. Not only has Pakistan seen a recent shift from small brands to wholesalers and shopping malls, but it has also seen a major revolution in the retail sector and is now an array of a wide range of international brands (such as Nike, Charles \& Keith, Swatch, Body Care) and major international wholesale chains (such as Metro, Carrefour and Wal-Mart).

Retail giants similar to Marks \& Spencer and Target Corporation are interested in initiating business operations in Pakistan. These biggest retail stores want to start their retailing business in Pakistan because they know that Pakistan is also a huge population country and very less restriction to start retailing business in Pakistan. The growth in Pakistan's retail sector is critical to maintaining its competitiveness in comparison with other Asian giants and neighbouring countries. India has the 5th largest global retail market. The total 
value of India retail industry is 353 billion and they expect that 200 billion increase at the end of this fiscal year. In India there are many retail giant have start their retailing operation. The giants of retailing sector are focus on Pakistan they know that the trend change in Pakistan. The Pakistani customer focus on the retailing sector and customer purchase their products from the biggest retail stores (Muneer et al., 2017). The customer does not purchase the products from local store they purchase products from big stores like ( AlFateh, Imtiaz super market, hyper star, metro cash and carry, macro cash and carry, chaseup store). Customer think that the big store have good quality products and available at low price as compare to local stores. This is very positive thing for the retailing industry.

The store brands play a very important role in the retailing industry. There are many store brands available on the store chains these store brands compete with the international brands. In the retail sector they are totally focus on their store brands because they play a very important role in maximizing profit of the store. If we talk about the cosmetics store brands, they have very huge competition in the market. Customer compares the cosmetics store brand with the international brand like (Nike, Burberry, and Polo). The store brands compete with price and quality with the international brands. Customer compares both of these factors while purchasing the store brands (Muir et al., 1996). These store brands also plays important role in increasing the profit of the store and store brands also create a differentiation and store loyalty. Currently the customers of the store brands are increase and due to increase in number of customer the store sales volume and market shares are increases, which have positive for the retail store (Alamanda, 2014). Recently, most of the retail store appears in the market with their own store brands and they did not prefer the manufacturer brands they introduce their own store brands variety (Amato et al., 2004). For attracting the customer and creating the customer loyalty the store brands helps the retailer by offering the product variety and product quality at best price. The objectives of our research are to measure the Effect of service quality on store image and measure the effect of service quality on brands label. Relationship between store image and brands label also one of the main objectives.

\section{Literature Review}

Martineau developed the idea of store image in (1958) and he described the store image as the mode in which the customer's mind pictures the store, sometime by its practical qualities and some time by its atmosphere of physical attributes. Grewal et al. (1998) said that a store's service quality level, consuming atmosphere or store environment and product quality are called store image. Retail store image has been displayed to perform a central part in store patronage, and it is extensively recognized that psychological aspects have an important role in store image development. Earlier research measure the tangible elements, or they find out the relationship between store images and impels buying behavior and customer satisfaction. Literature review is discovering the link between perceived store image and perceived service quality and private brand labeling. Store images elements are "nice feeling" to the physical attributes of "price", "quality" and "reputation". The construction of store image consist on best service quality, suitable price, customers satisfactions (Thompson \& Ling Chen, 1998). Store arrangement and design should be promoted to increase the convenience of the buyers. Experienced and well-trained salespersons can also help to reduce the problems in consumers buying process and lead to impulse purchasing behavior (Crawford and Melewar, 2003).

Earlier studies have established relationship between store image and brands label. They find out the direct and positive effect of store image on consumer evaluation regarding brands label (Muir et al., 1996b). Rao and Monroe (1989) conducted a research, in their studies they compared two elements of brand one is brand name and the other is price of the brand. In their study they conducted the research on apparel products they created the effect of store image on perceived quality of apparel products. Vahie and Paswan (2006) conducted a research on student's perception. In their research they check two variables are store image and brands label. In their research they found that single variable store atmosphere had a positive impact on apparent quality of brands label. They said that price and image of the store had positively impacted on satisfaction with private labeled clothes. On the other, Collins-Dodd and Lindley (2003) conducted their research on food products. In their research they found that there is a weak support and weak relation between store image and brands label of food for one of three stores. There is just store variety and 
atmosphere was significant. Store image is also increase by the quality of product there is positive relationship between product quality and the store image (Baker et al., 1994).

Private label brand (PLB) of cosmetics is also known as store brands of cosmetics, or own brands of cosmetics, and retailer sold by its own outlets. Like on Imtiaz super market there is Shan and Imtex are their own brands label they are just available on Imtiaz super market. According to Jin and Suh, (2005) most of customers factors linked with private label brand behavior of purchasing can be based on three classifications such as personality, socioeconomic (Baltas and Argouslidis, 2007) and perceptual (Garretson et al., 2002). In earlier studies consumers widely investigated perceptual features such as service-quality, value, perceived quality and price consciousness (Baltas and Argouslidis, 2007). We think that purchase intention refer to a consumer tendency to purchase a brand regularly in the future and resist switching to other brands. Also literature shows that image factor (store image) and service quality perception are important elements of Private label brand purchase intention (Diallo, 2012).

In literature, the term is also defined as "store brand" or "retailer brand" (Lincoln and Thomassen, 2008). As shown in a study of the year 2016 by the universal information and measurement company Nielsen (2003), $70 \%$ of European respondents or customers believe in private labels being a good alternative to manufacturer brands. In addition, the market shares in Europe in 2016 grew up to $45 \%$ in some countries (Nielsen, 2003). With these high market shares and strong believes in favor of private labels, the significance is obvious. Overall, private branding is a mature industry and the private label products are already in most of consumers' homes (Shankar et al., 2012).

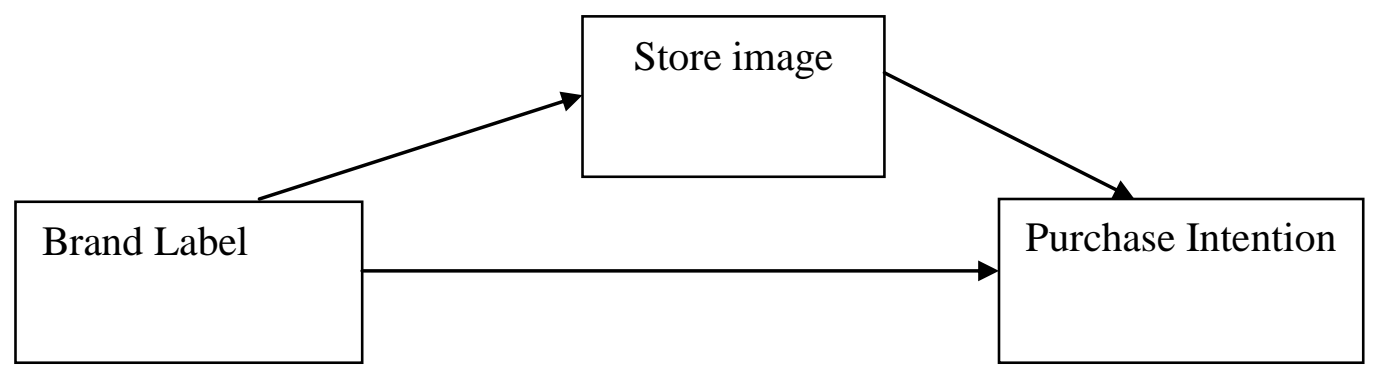

\section{Methodology}

This study is conducted in Lahore\& Karachi District. The reason of conducting the study in Pakistan State because of the changing consumer minds day by day intention towards retail stores in Pakistan. In order to gather primary data a self-administered questionnaire is formed as a research instrument. It consists of service quality, store image, PLB in retail stores. In our study measurement scale is used in questionnaire we developed from prior studies. The population in this research was customers of the different retail stores of Lahore and Karachi. Snowball sampling technique used was used to increase the accuracy of data. For collection of data the questionnaire was delivering directly to the 200 respondents. Data was analyzed by Partial least squares model (PLS). This PLS was used for casual molding approach i.e. evaluation of the structural model and measurement model.

\section{Results}

In the current study statistical software SPSS is used in order to test path model. In the field of behavioural research and communication related to casual relationships, partial least squares PLS is used, which is a type of structural equation modelling (SEM). Current research uses structural equation modelling in order to examine casual models. A statistical technique used to simultaneously prove the causal relationship - not a piecemeal approach. SEM offers a wide range of adaptable and flexible casual modelling scenarios (Hair et al., 2011). To attain higher theoretical simplicity and lower model complexity, PLS-Path models or componentbased structural equation modelling allow for the evaluation of hierarchical models (Hair et al. 2014). PLSMulti group analysis was also used to assess mediators who adjusted moderately self-evaluators and low- 


\section{Journal of Social and Development Sciences (ISSN 2221-1152)}

Vol. 10, No. 2, pp. 44-51, June 2019

core self-evaluators. The current study sample size is $\boldsymbol{n}=\mathbf{2 0 0}$. The relationship between construction and related items is specified by an external or measurement model, although the structural model defines the relationship between construction items as shown below (Figure 1).

\section{Figure 1: Structural Model}

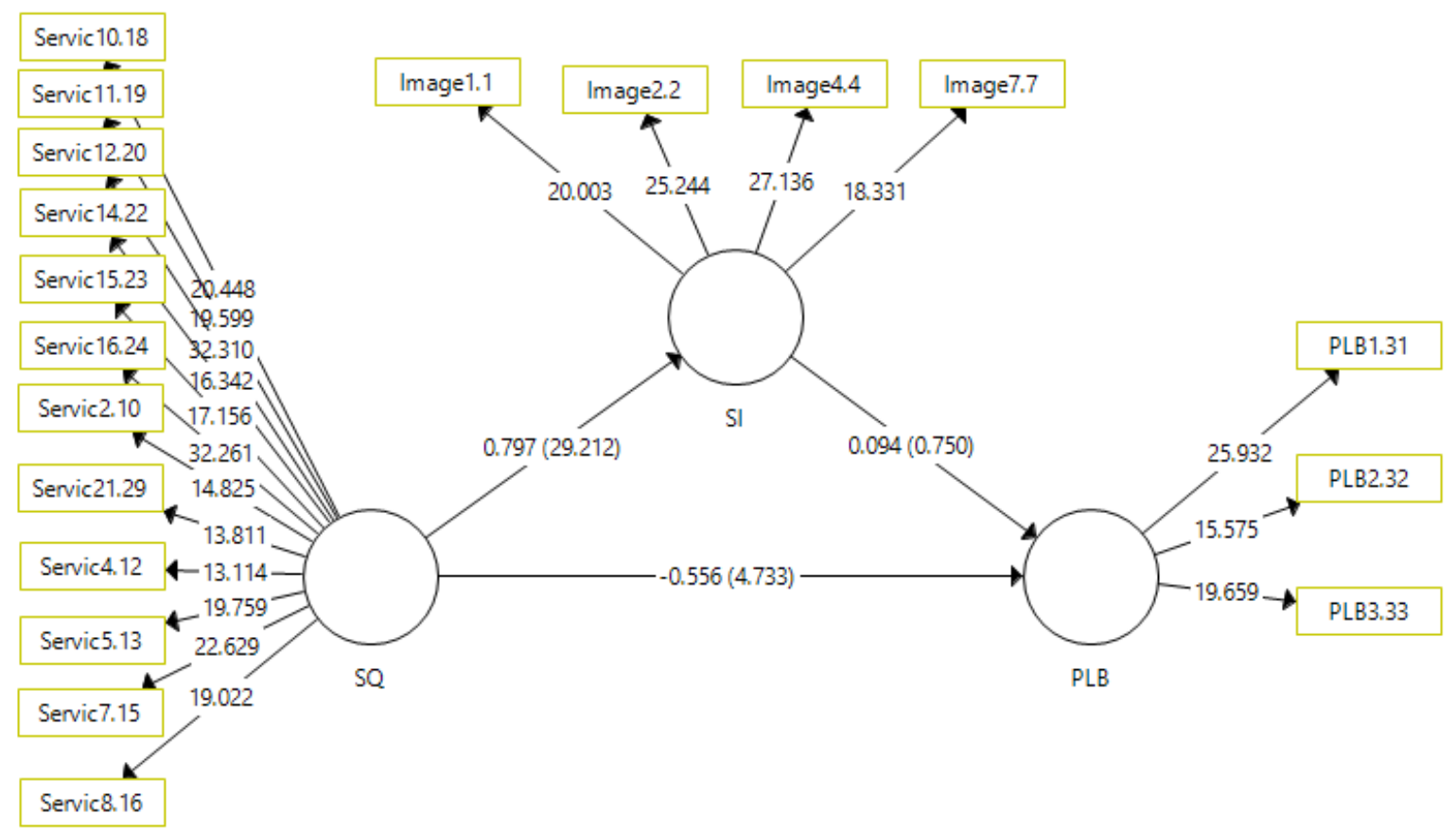

Discriminant validity and convergent validity are utilized to validate the Model. CR and AVE are used for validity convergence. All values of AVE and CR should be higher than 0.5 and 0.7 respectively. Fornell and Larcker (1981) criterion is used to check discriminant validity of model. This study represents that the indicators variance is more shared with the construct compared to some other construct. It is required for testing that the maximum squared correlation with other construct should be lower than the AVE value of each construct. Cross Loadings is utilized in order to check model's discriminant validity. This strategy, frequently viewed as more liberal. Henseler et al., (2009) concludes that the cross loadings on different constructs is lower than the loadings of every indicator on its construct. Specifically tailored questionnaire are developed for the data collection of this research. In this study, reward system, employee motivation, core self-evaluation and patient oriented behavior was analyzed. Initially, models of reflective measurement should be assessed for their validity and reliability (i.e., convergent validity and discriminant validity) we used PLS-algorithm (Fig 2). As per our observation, for the indicator reliability, 19 out of 35 indicators consist of outer loadings of over 0.70 (Table 1) \& (Fig. 2). 
Figure 2: Working Algorithm

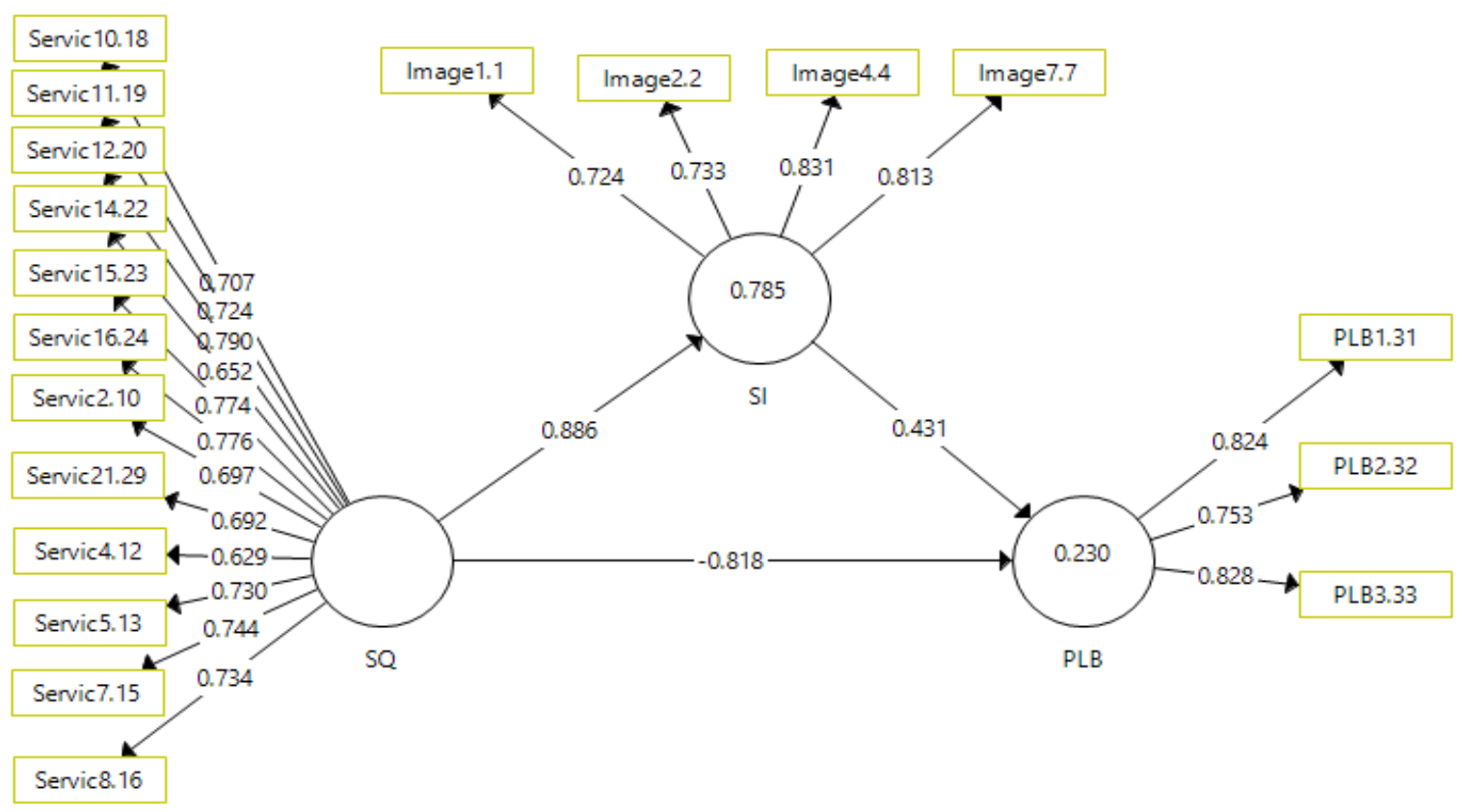

In total 8 indicators of Store image are used, 4 out of the total 8 indicators have an overall reliable outer loading. And 5 indicators of Store image were used, 3 of the 5 indicators have reliable outer loading. In Service Quality have 22 indicators in which 12 are reliable. We considered 12 out of 22 indicators of Service Quality for reliability. Note: items SI3, 5, 6, 8, SQ1, 2, 3, 6, 9, 13, 17, 18, 19, 20, 22, and PLB33, 34 were deleted to improve Ep. Thus, the models' indicators for reflective measurement reach satisfactory level of indicator's reliability. According to (Nunnally, 1978), the reflective measurement models accomplish combined reliability values of 0.885 and greater. Table 3 provides the evidence of the internal consistent reliability of the construct measures. Likewise, as presented in Table 3 all of the values of AVE-Average variance are greater than the 0.5 threshold.

\section{Table 1: Relevance and Predictive Accuracy of the Model}

\begin{tabular}{lcc}
\hline \hline Indices of Goodness of fit & R-Square $\left(\mathbf{R}^{2}\right)$ & $\left(\mathbf{Q}^{2}\right)$ \\
\hline \hline Brands Label & 0.230 & 0.220 \\
Store Image & 0.785 & 0.784 \\
\hline \hline
\end{tabular}

We executed the PLS-B Bootstrapping in order to connect the hypothesis relationships between variables of the model, as shown in (Figure 2). Figure 2 provides path coefficients estimates. The path coefficient value are consistent between a range of " -1 to +1 ". Path coefficient closer to " +1 " indicates strong positive relationship. Similarly strong negative relationship is indicated by the path value of coefficient closer to "- 1 ". Statistically a standardized error can be reached (Anselmsson et al., 2008) even with the coefficient values closer to -1 or either +1 . It is achieved by bootstrapping test for significance. 
Table 2: t-Statistics and Path Coefficient

\begin{tabular}{lccc}
\hline \hline Path of Research model & $\begin{array}{l}\text { Path- } \\
\text { Coefficients }\end{array}$ & SD & t -values \\
\hline \hline Store Image $\rightarrow$ P. Intention & 0.431 & 0.154 & 2.804 \\
Brands Label $\rightarrow$ P. Intention & -0.818 & 0.122 & 6.701 \\
Brands Label $\rightarrow$ Store Image & 0.886 & 0.02 & 43.229 \\
\hline
\end{tabular}

Table 2 represents that the strong positive significant relationship among the constructs that are indicated by the values of path coefficients instead of one relationship. Store Image has a significant effect on Private Label Brand as the $(\beta=0.431, S . D=0.154 \& t$-value $=2.804)$. The Store Image is effected by Service Quality with the $(\beta=0.886$ S.D $=0.02 \& \mathrm{t}$-value $=43.229)$. Service Quality does not apply significant effect on the Private Label Brand $(\beta=-0.818$ S.D $=0.122 \& \mathrm{t}$-value $=6.701)$. This Analysis is conducted using Smart-PLS 3.0. All Hypotheses are tested using PLS-blindfolding, PLS-algorithm and PLS-bootstrapping. We substituted latent variables in model and connected them in path. Service quality is declared as an independent variable, store image as a mediation, and finally private label brand as a dependent variable.

Figure 3: Bootstrapping PLS

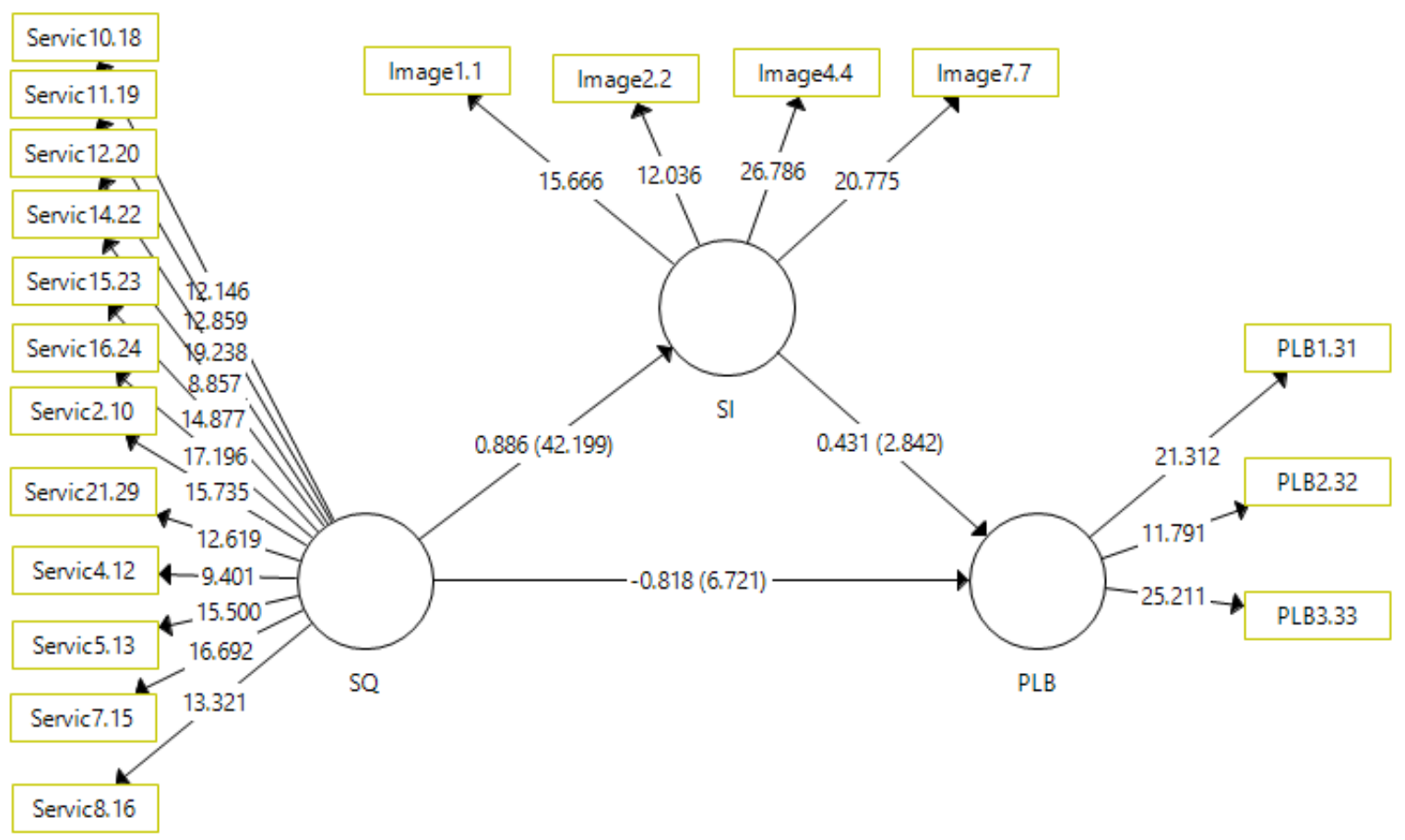

The influence of service quality to enhance the private label brand and store image is hypothesized. Table 8represents the outcomes that supports the Hypothesis H1 \& Hypothesis H2. Hypothesis 1 shows that service quality have positive and significant effect on store image showing Hypothesis (1) was supported $(\beta=0.886$, t- value $=43.229$, $\mathrm{p}$-value $=0$ ). Hypothesis 2 forecasts the store image has effect on private label brand. The results designate that store image, $(\beta=0.431$, t-value $=2.804$ and $p$-value $<0.05=0)$ has a noteworthy effect 
on private label brand, thus supports H2. (Table 8).Hypothesis 3 proposed the service quality has significant but negative effects on PLB, According to the push and pull effect (Khuong \& Ha, 2014). The result points that service quality $(\beta=-0.818$, t-value $=6.701$, p-value $<0.05=0)$ significantly but negativity influenced private label brand: supporting Hypothesis (3) (Table 8). Hypothesis 4 predicts that store image mediates the relationship between service quality and private label brand. The direct relation is significant as per our findings, the beta value of direct effect of service quality and store image on PLB $(\beta=-0.818$; $t$ - value $=6.701$ p-value $=0.00)$ and indirect effect $(\beta=0.382$, $\mathrm{t}$-value $=2.743$ and $\mathrm{p}$-value $0.006=0)$ was significant supporting hypothesis (4).store image have significant but positive direct effect and significant but negative indirect effect meditation so this mediation is regularly partial mediation (Nitizl et al, 2016). The standardized coefficient of the indirect effect of SQ on PLB is .382 ( $\mathrm{t}=2.743)$, which is significant at .006 level.

Table 3: Relationships in Hypothesis

\begin{tabular}{|c|c|c|c|c|c|}
\hline Hypothesis & Coefficients Path & t-value & p-value & $\begin{array}{c}\text { Impact } \\
\text { Anticipated }\end{array}$ & Verdict \\
\hline $\boldsymbol{H}_{1}$ & 0.886 & 43.229 & 0 & Positive & Supported \\
\hline $\mathrm{H}_{2}$ & 0.431 & 2.84 & $0.005^{* * *}$ & Positive & Supported \\
\hline $\mathrm{H}_{3}$ & -0.818 & 6.701 & $0^{* * *}$ & Positive & Supported \\
\hline $\mathrm{H}_{4}$ & 0.818 & 6.701 & $0^{* * *}$ & Positive & Supported \\
\hline
\end{tabular}

Note: Coefficients of Path: ${ }^{*} p, 0.05,{ }^{* *} p, 0.01$ level, ${ }^{* * *}$ p, 0.001 level. Negatives: Non-significant. Control variables are not presented in the model for simplicity.

\section{Conclusion}

This study was about the impact of store image on purchasing intention of the labelled brands of cosmetics. Good brands label leads to good store image between the customers mind. When the store image is good the customer purchase the brands label of cosmetics of that store. We focus on the brands label of the store which is very helpful for creating the good store image of that store. The outcomes of our study show that store service quality effect the store image of the store and store image leads to increase the purchase intention of the customer towards the brands label of cosmetics.

\section{References}

Alamanda, D. T. (2014, October). Mapping of Tablet PC Based On Consumer Perception (Case Study of Bandung Electronic Center Visitors) Dini Turipanam Alamanda, Gamal Argi 2, Arif Partono 3 Telkom University, Bandung, Indonesia aturipanama@ gmail. com, 081222720568. In Jurnal Manajemen Bisnis Indonesia. Publisher: Forum Manajemen Indonesia.

Amato, S., Esposito Vinzi, V., Tenenhaus, M. (2004). A global goodness-of-fit index for PLS structural equation modeling. Oral communication to PLS club, March 24th 2004, HEC School of Management, France.

Anselmsson, J., Johansson, U., Maranon, A., Persson, N., 2008. The penetration of Retailer brands and the 
impact on consumer prices - a study based on household expenditures for 35 grocery categories. Journal of Retailing and Consumer Services 15 (1), 42-51.

Baker, J., Grewal, D., \& Parasuraman, A. (1994). The influence of store environment on quality inferences and store image. Journal of the academy of marketing science, 22(4), 328-339.

Baltas, G., \& Argouslidis, P. C. (2007). Consumer characteristics and demand for store brands. International Journal of Retail \& Distribution Management, 35(5), 328-341.

Collins-Dodd, C., \& Lindley, T. (2003). Store brands and retail differentiation: the influence of store image and store brand attitude on store own brand perceptions. Journal of Retailing and Consumer Services, 10(6), 345-352.

Crawford, G., \& Melewar, T. C. (2003). The importance of impulse purchasing behaviour in the international airport environment. Journal of Consumer behaviour, 3(1), 85-98.

Diallo, M. F. (2012). Effects of store image and store brand price-image on store brand purchase intention: Application to an emerging market. Journal of Retailing and Consumer Services, 19(3), 360-367.

Fornell, C., \& Larcker, D. F. (1981). Structural equation models with unobservable variables and measurement error: Algebra and statistics. Journal of marketing research, 382-388.

Garretson, J. A., Fisher, D., \& Burton, S. (2002). Antecedents of private label attitude and national brand promotion attitude: similarities and differences. Journal of Retailing, 78(2), 91-99.

Grewal, D., Krishnan, R., Baker, J., \& Borin, N. (1998). The effect of store name, brand name and price discounts on consumers' evaluations and purchase intentions. Journal of retailing, 74(3), 331-352.

Hair Jr, J. F., \& Lukas, B. (2014). Marketing research (Vol. 2). McGraw-Hill Education Australia.

Hair, J. F., Ringle, C. M., \& Sarstedt, M. (2011). PLS-SEM: Indeed a silver bullet. Journal of Marketing theory and Practice, 19(2), 139-152.

Henseler, J., Ringle, C. M., \& Sinkovics, R. R. (2009). The use of partial least squares path modeling in international marketing. In New challenges to international marketing (pp. 277-319). Emerald Group Publishing Limited.

Khuong, M. N., \& Ha, H. T. T. (2014). The Influences of Push and Pull Factors on the International Leisure Tourists' Return Intention to Ho Chi Minh City, Vietnam--A Mediation Analysis of Destination Satisfaction. International Journal of Trade, Economics and Finance, 5(6), 490.

Lincoln, K., \& Thomassen, L. (2008). Private label: turning the retail brand threat into your biggest opportunity. Kogan Page Publishers.

Martineau, P. (1958). The personality of the retail store.

Muir; Haynes, R. Brian \& Richardson, W. Scott (1996). Evidence based medicine: What it is and what it isn't. British Medical Journal, 312, 71-72.

Muneer, S., Tufail, M. S., Jamil, K. \& Zubair, A. (2017). Impact of Capital Market Expansion on Company's Capital Structure. NFC IEFR Journal of Engineering and Scientific Research, 5.0

Nielsen, A. C. (2003). Europe, US still largest private label markets, but other regions seeing huge growth fuelled by retailer expansion. Canadian Corporate News, September 2003.

Nunnally, J.C. (1978), Psychometric Theory, 2nd ed., McGraw-Hill Book Company, New York, NY.

Rao, A. R., \& Monroe, K. B. (1989). The effect of price, brand name, and store name on buyers' perceptions of product quality: An integrative review. Journal of marketing Research, 351-357.

Russell, J. A., \& Pratt, G. (1980). A description of the affective quality attributed to environments. Journal of personality and social psychology, 38(2), 311.

Shankar, V., Carpenter, G. S., \& Farley, J. (Eds.). (2012). Handbook of marketing strategy. Edward Elgar Publishing.

Thompson, K. E., \& Ling Chen, Y. (1998). Retail store image: a means-end approach. Journal of Marketing Practice: Applied Marketing Science, 4(6), 161-173.

Vahie, A., \& Paswan, A. (2006). Private label brand image: its relationship with store image and national brand. International Journal of Retail \& Distribution Management, 34(1), 67-84. 